\section{Smoking and death}

\section{Public health measures were taken more than $\mathbf{4 0}$ years ago}

Edrror,-Richard Peto discusses the failure of public health with regard to smoking over the past 40 years, ${ }^{1}$ but his account could have extended back further. He considers that the Medical Research Council was, in 1957, "the first national institution in the world to accept formally the evidence that tobacco is a major cause of death." The formal recognition of this fact, however, was explicitly made by many important national institutions in Nazi Germany. The Public Health Office and the German Medical Association, both under the leadership of Dr Gerhard Wagner, repeatedly issued precise pronouncements regarding the dire health consequences of smoking. By 1939 Wagner's successor, Dr Leonardo Conti, had established the Reich Bureau Against the Dangers of Alcohol and Tobacco. ${ }^{2}$ The Reich Health Office also made numerous statements, which its president, Hans Reiter, reiterated at his inaugural address at the opening of the "first scientific institute for the struggle against the dangers of tobacco" at the University of Jena in 1942. ${ }^{3}$ The German Labour Front, under the leadership of Robert Ley, ran many campaigns highlighting the damaging effects of tobacco on health. Like Adolf Hitler, Reiter, Ley, Wagner, and Conti were, publicly at least, vehemently against smoking. ${ }^{245}$

Recognition of the damaging effects of smoking on health led to much antismoking legislation ${ }^{6}$; this included legislation banning smoking in public places by those under 18 and prohibiting both tobacco advertising and smoking in public buildings and on public transport. Pregnant women and those deemed to be sick because of smoking had their tobacco rations withdrawn, and there was serious discussion regarding whether those sick with illness caused by smoking should receive medical care equal to that given to patients whose illnesses were not considered to be self inflicted. ${ }^{5}$

Odds ratios (95\% confidence intervals) for lung cancer, with different control groups, calculated from data of Schairer and Schöniger ${ }^{8}$

\begin{tabular}{lccc}
\hline & \multicolumn{3}{c}{ Control group } \\
\cline { 2 - 4 } $\begin{array}{l}\text { Smoking } \\
\text { category }\end{array}$ & $\begin{array}{c}\text { General } \\
\text { population }\end{array}$ & $\begin{array}{c}\text { All other } \\
\text { cancers }\end{array}$ & $\begin{array}{c}\text { Cancers unrelated } \\
\text { to smoking* }\end{array}$ \\
\hline Very heavy & $16.6(4$ to 91$)$ & $8.8(2$ to 49$)$ & $10.4(3$ to 58$)$ \\
Heavy & $5.8(2$ to 32$)$ & $5.6(1$ to 32$)$ & $6.6(2$ to 38$)$ \\
Medium & $7.8(2$ to 42$)$ & $7.0(2$ to 38$)$ & $7.7(23$ to 42$)$ \\
Moderate & $1.6(0.4$ to 9$)$ & $1.4(0.4$ to 9$)$ & $1.4(0.3$ to 8$)$ \\
Non-smoker & 1.0 & 1.0 & 1.0 \\
$\begin{array}{l}\text { Test for trend } \\
\text { (P value) }\end{array}$ & $<0.00001$ & $<0.00001$ & $<0.00001$ \\
\hline
\end{tabular}

^As defined in study.

Research continued alongside these campaigns against smoking. Many would think that the casecontrol study of smoking and lung cancer conducted by Schöniger constituted clear evidence that smoking was a major cause of death. ${ }^{78}$ This study avoided one of the methodological problems of later studies by including both general population controls and hospital controls and investigated whether changes in smoking consequent on sickness could have biased the results. The findings indicated strong risks-similar in magnitude to those found by later studies-whatever control group was used (table); these risks were not explicable in terms of changes in smoking behaviour induced by illness. Schöninger's study cost 173.30 of the 100000 Reichsmark given by Adolf Hitler from his personal funds to the Jena Institute.

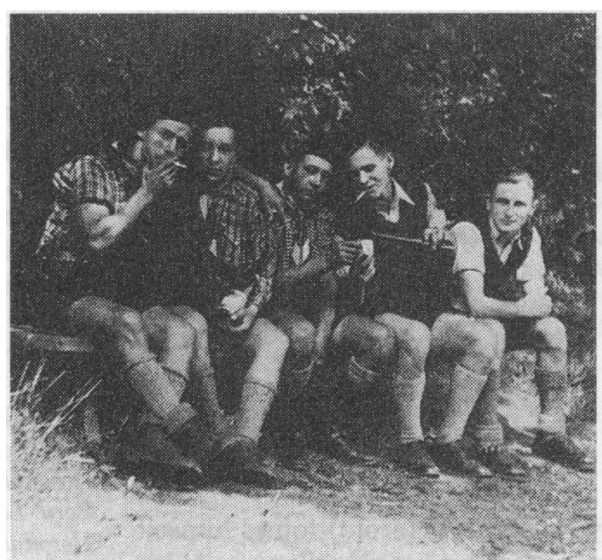

Edelweiss Pirates enjoy a cigarette: was smoking a way of showing disobedience in Nazi Germany? (Reproduced from ref 11 by permission of the publisher)

The antismoking activities in Nazi Germany were tied, institutionally and ideologically, to the racial hygiene movement, ${ }^{6}$ which . was deeply implicated in the murder campaigns against Jews, homosexuals, travellers, and those deemed to be mentally and physically defective. ${ }^{\prime}$ Tobacco was considered to be a "genetic poison," decreasing fertility and increasing the incidence of chromosomal damage.

The Jena Institute carried out both clinical and animal research into these topics. ${ }^{10}$ For the anti-Nazi youth movements-the working class Edelweiss Pirates and the bourgeois Hamburg Swing Youth alike-the constant cigarette seems to have been almost a badge of resistance (figure) and was referred to as a sure indicator of their degeneracy in the surveillance reports produced by the Hitler Youth. ${ }^{11}{ }^{12}$ Indeed, one of the reasons for the relative failure of activities to prevent smoking in Germany since the war $^{13}$ may be that the association of authoritarian antismoking efforts with the Nazi regime remained in popular memory for a long period. ${ }^{6}$

A travel grant from the Wellcome Trust allowed inspection of relevant archives, including those of the Institute for the Struggle against the Dangers of Tobacco.

\section{University of Bristol,} Bristol BS8 2PR

GEORGE DAVEY SMITH Institute of Medical Sociology, Professor of clinical epidemiolog University of Hamburg Hamburg,

Germany

SABINE STRÖBELE Teaching associate

Department of Social and Preventive Medicine, University of Berne,

$\mathrm{CH}-3012$ Beme,
1 Peto R. Smoking and death: the past $\mathbf{4 0}$ years and the next $\mathbf{4 0 .}$ BMF 1994;309:937-9. (8 October.)

2 Proctor RN. Racial hygiene. Medicine under the Nazis. Cambridge MA: Harvard University Press, 1988.

3 Reiter H. Ansprache bei der Eroffnung des 1. Wissenschaftlichen Instituts zur Erforschung der Tabakgefahren an der Friedrich-Schiller-Universităt Jena am 5 April 1941. der Friedrich-Schiller-Universităt Jena am 5 April

4 Berlin: stimulants endanger public health. JAMA 1939;12: 2339-40.

5 Lickint F. Tabak und Organismus. Sturtgart: HippokratesVerlag, 1939.

6 Davey Smith G, Strobbele SA, Egger M. Smoking and health promotion in Nazi Germany. I Epidemiol Community Health promotion in $1994 ; 48: 220-3$.

7 Schairer E, Schơniger E. Lungenkrebs und Tabakverbrauch. Zeitschrift fir Krebsforschung 1943;54:261-9.

8 Schőniger E. Lungenkrebs und Tabakverbrauch: InauguralDissertation zur Erlangung des Doktorgrades einer Hohen Medizinischen Fakultät der Friedrich-Schiller-Universität zu Jena. Jena: Friedrich-Schiller-Universităt, 1944.

9 Burleigh M, Wippermann W. The racial state: Germany 19331945. Cambridge: Cambridge University Press, 1991.

10 Bernhard P. Der Einfluß der Tabakgifte auf die Gesundheit und die Fruchtbarkeit der Frau. Jena: Verlag von Gustav Fischer, 1943.

11 Breyvogel W, ed. Piraten, Swings und Funge Garde: Fudendwiderstand im Nationalsozialismus. Bonn: Dietz, 1991.

12 Peukert DJK. Inside Nazi Germany: conformity, opposition and racism in everyday life. London: $\mathrm{BT}$ Batsford, 1987.

13 Brenner H. A birth cohort analysis of the smoking epidemic in West Germany. I Epidemiol Community Health 1993;47:54-8.

\section{Author's reply}

EDrToR,-A qualitative difference exists between the strength of the scientific evidence about cigarette smoking and lung cancer that was available in the 1930s and that available in the 1950s. Assertions by German institutions in the 1930s can hardly be described as "acceptance of the evidence" as they predated even the early publications of the studies by Müller and Schairer and Schöniger on lung cancer, ${ }^{12}$ and the evidence on other major diseases came still later. In retrospect, those and other early publications, such as the analyses in 1938 by Pearl of total mortality from smoking among holders of life insurance policies in the United States, ${ }^{3}$ should have been taken more seriously by medical scientists, but even in the late 1940s they were not. Moreover, both of the German studies were small (with a total of 179 lung cancers, as against 2150 in the publications in 1948-504). Thus what distinguished the official statements about smoking by the British and other authorities in the late 1950s was that they represented, for the first time, a consensus based on substantial evidence.

Finally, there are no obvious ties between the Nazi campaigns of racial murder and the current antismoking movement-rather the reverse, in fact, since Hitler before 1945 and tobacco since 1945 both caused about 50 million deaths.

RICHARD PETO Professor of medical statistics and epidemiology

ICRF Cancer Studies Unit,

Radcliffe Infirmary, Oxford OX2 6HE

1 Müller FH. Tabakmissbrauch und Lungencarcinom. Zeitschrift für Krebsforschung 1939;49:57-85.

2 Schairer E, Schöniger E. Lungenkrebs und Tabakverbrauch. Zeitschrift firr Krebsforchung 1943;54:261-9.

3 Pearl R. Tobacco smoking and longevity. Science 1938;87:216-7.

4 Doll R. Introduction and overview. In: Samet JM, ed. Epidemiology of lung cancer. New York: Marcel Dekker, 1994: 1-14.

5 Peto R, Lopez AD, Boreham J, Thun M, Heath C Jr. Morrality from smoking in developed countries 1950-2000. Oxford: Oxford University Press, 1994. 